\title{
UPAYA PEMBERDAYAAN PEREMPUAN MELALUI PELATIHAN LITERASI INFORMASI KESEHATAN PADA IBU-IBU KADER PKK
}

\author{
Komariah, N, Prijana, dan Winoto, $Y$ \\ Program Studi Ilmu Perpustakaan Fakultas Ilmu Komunikasi, Universitas Padjadjaran \\ E-mail: neneng.komariah@unpad.ac.id
}

\begin{abstract}
ABSTRAK.Kemampuan literasi informasi sebagai kemampuan dasar yang seharusnya dimiliki oleh setiap orang karena literasi informasi merupakan prasyarat untuk mampu belajar mandiri sepanjang hayat (lifelong learning). Kecamatan Jatinangor berada di wilayah Kabupaten Sumedang yang masih mempunyai beberapa masalah kesehatan lingkungan diantaranya sarana dan pelayanan kesehatan yang belum memadai di daerah pinggiran; banjir, dan kekurangan air saat kemarau. Ibu rumah tangga memiliki peran penting dalam usaha pemeliharaan kesehatan keluarga dan kesehatan lingkungan di suatu wilayah.Kegiatan PKM yang telah dilaksanakan berupa upaya pemberdayaan perempuan melalui pelatihan literasi informasi kesehatan lingkungan bagi para ibu-ibu kader PKK di Kecamatan Jatinangor. Tujuan kegiatan adalah agar para ibu kader PKK memiliki literasi informasi kesehatan khususnya kesehatan lingkungan agar mereka mampu menyadari masalah kesehatan lingkungan yang ada di sekitarnya, mampu mencari dan menemukan informasi yang relevan dengan masalah yang dihadapi, mampu mengevaluasi kualitas informasi yang diperoleh dan mampu merumuskan informasi yang diperoleh untuk mengatasi masalah yang dihadapi, serta mampu mengkomunikasikan informasi tersebut pada orang lain(masyarakat). Metode pelatihan terdiri dari penyampaian materi berupa ceramah tentang kesehatan lingkungan dilanjutkan dengan praktek aplikasi langkah-langkah literasi informasi kesehatan lingkungan. Hasil pelaksanaan dapat diketahui bahwa ibu-ibu kader PKK yang mengikuti pelatihan telah memiliki kemampuan literasi informasi kesehatan lingkungan dan mereka bersedia untuk menularkan pengetahuannya pada ibu-ibu yang lain yang merupakan anggota kelompoknya.
\end{abstract}

Kata kunci: pemberdayaan perempuan, kesehatan lingkungan, literasi informasi.

\section{WOMEN EMPOWERMENT MEETING THROUGH HEALTH INFORMATION LITERATURE TRAINING TRAINING AMONG PKK CADRES}

\begin{abstract}
Information literacy skill is a basic skill that should be owned by people, because it is a prerequesite for lifelong learning. Jatinangor District is located in Sumedang Regency which has some health problems those are bad health infrastucture in rural area, flood in rainy season, and less clean water. Housewive has an important role in look after family and environment health. The PKM held was a training of health information literacy skill as women empowerment for PKK cadre at Jatinangor District.The objective was the PKK cadres should have health information literacy skill that consists of awerness of health environment problems, be able to find relevant information, be able to evaluate quality of information and use the information in solving the health problem, and be able to communicate the new information to people around them. Based on focus group discussion as an evaluation method the PKK cadres had information literacy skills and they will inform their member group about the skill.
\end{abstract}

Key words: women empowerment, information literacy, health information.

\section{PENDAHULUAN}

Kesehatan lingkungan merupakan hal yang sangat penting dalam kehidupan masyarakat, karena hidup di tengah lingkungan yang sehat akan membuat manusia sebagai anggota masyarakat merasa nyaman. Disamping itu, lingkungan yang sehat juga sangat dibutuhkan untuk mendukung terciptanya tubuh yang sehat pada seluruh anggota masyarakat yang tinggal di suatu wilayah.

Penciptaan lingkungan yang sehat tidak terlepas dari peran seorang ibu rumah tangga, karena kesehatan lingkungan dimulai dari pemeliharaan kesehatan di lingkungan rumah yang selanjutnya meluas pada pemeliharaan kesehatan lingkungan di masyarakat secara luas. Oleh karena itu informasi tentang kesehatan lingkungan akan sangat diperlukan oleh para ibu rumah tangga.
Ketika seseorang membutuhkan informasi, dia bisa mendapatkan informasi dari berbagai sumber. Mulai dari bertanya pada seseorang, mencari melalui media seperti membaca buku, membaca surat kabar, menonton televisi, mendengarkan radio, mengakses interne dan lain-lain.

Menurut American Library Association (1998), literasi informasi merupakan kemampuan untuk menyadari kapan informasi diperlukan, dan kemampuan untuk menemukan, mengevaluasi, dan menggunakan secara efektif informasi tersebut.Berkaitan dengan informasi kesehatan lingkungan, sering dijumpai situasi dimana orang abai terhadap hal tersebut. Misalnya ketika terjadi pencemaran sungai oleh limbah industri banyak masyarakat yang tidak tahu harus berbuat apa. Hal ini tentu saja akan sangat merugikan masyarakat. Oleh karena itu sudah saatnya masyarakat memiliki kemampuan literasi informasi dalam hal ini literasi informasi tentang kesehatan lingkungan. 
Pelatihan literasi informasi kesehatan lingkungan bertujuan menjadikan masyarakat memiliki kemampuan untuk menyadari adanya permasalahan yang berkaitan dengan kesehatan lingkungan dan untuk mengatasinya membutuhkan informasi, mengetahui ke mana harus mencari informasi yang dibutuhkan, mampu mengevaluasi kualitas informasi yang diperoleh, dan mampu menggunakan informasi yang diperoleh secara efektif.

Seperti sudah disebutkan sebelumnya bahwa para ibu rumah tangga memiliki peran strategis dalam penciptaan dan pemeliharaan kesehatan lingkungan, maka target pelatihan literasi informasi adalah para ibu rumah tangga dalam hal ini ibu-ibu yang menjadi kader PKK. Pemilihan ibu-ibu kader PKK sebagai target adalah karena mereka diharapkan akan mampu menularkan kemampuan literasi informasi kesehatan lingkungan yang telah diperolehnya dalam pelatihan kepada ibu-ibu lain yang berada di sekitarnya.

Kecamatan Jatinangor merupakan salah satu kecamatan yang berada di wilayah Kabupaten Sumedang. Secara administratif Kecamatan Jatinangor terbagi ke dalam 12 Desa, 56 Dusun, 128 RW dan 479 RT. Kondisi Demografis Kecamatan Jatinangor antara lain jumlah penduduk berdasarkan hasil Pendataan Keluarga Tahun 2008 adalah sebanyak 87.974 Jiwa, yang terdiri dari 44.151 orang laki-laki, 43.821 orang perempuan. Adapun jumlah Kepala Keluarga (KK)sebanyak 20.525. Laju Pertumbuhan Penduduk Kecamatan Jatinangor termasuk tinggi secara relatif yaitu sebesar 2,04\% per tahun (tahun 2007), bila dibandingkan dengan angka laju pertumbuhan penduduk kabupaten sebesar 1,9\%. Hal ini menunjukan bahwa bukan saja tingkat kelahiran bayi masih tinggi tapi juga, sebagai kawasan pendidikan dan industri, Kecamatan Jatinangor sangat menarik bagi pendatang, baik dari lokal maupun nasional. (http://dokumen.tips/ documents/keadaan-umum-jatinangor).

Yuniarti (2015) menyebutkan dampak dari kawasan industri yang teridentifikasi di Jatinangor saat ini cenderung menjadi akumulasi permasalahan di lapangan. Persoalan diketahui ketika diadakan pertemuan yang khusus membahas tentang persoalan Jatinangor. Persoalan tersebut diantaranya: sarana dan pelayanan kesehatan yang tidak memadai di daerah pinggiran; gundulnya area konservasi atau lereng gunung; banjir limpahan dari daerah terbangun seperti dari kawasan perguruan tinggi; kekurangan air saat kemarau; serta kurangnya kesempatan kerja bagi masyarakat lokal.

Masalah kesehatan merupakan salah satu persoalan yang perlu mendapat perhatian khusus, dalam hal ini di wilayah Kecamatan Jatinagor karena semua orang baik secara pribadi, kelompok atau masyarakat kapan dan dimana saja, mempunyai hak untuk dapat hidup sehat. Selain itu, setiap orang baik pribadi, kelompok, maupun masyarakat juga mempunyai kewajiban dan tanggungjawab menjaga kesehatan dari penyakit dan mencegah dari masalah kesehatan. Untuk itu setiap pribadi dituntut mempunyai kemampuan mandiri (self reliance) dalam memelihara dan melindungi kesehatan mereka.

Menurut Undang-undang Nomor 36 Tahun 2009 tentang Kesehatan pada Pasal 1 dijelaskan bahwa "Kesehatan adalah keadaan sehat, baik secara fisik, mental, spritual maupun sosial yang memungkinkan setiap orang untuk hidup produktif secara sosial dan ekonomis". Hingga dapat diketahui bahwa ukuran kesehatan tidak hanya aspek fisik, mental, sosial saja, tapi juga termasuk aspek produktivitas secara ekonomi maupun produktif secara sosial.

Masih rendahnya pengetahuan masyarakat akan pentingnya menjaga kesehatan lingkungan dan bagaimana mengatasi masalah yang berkaitan dengan kesehatan lingkungan, mendorong tim kami untuk mengadakan pelatihan literasi informasi kesehatan lingkungan pada ibu-ibu kader PKK di Kecamatan Jatinangor.

Menurut Himpunan Ahli Kesehatan Lingkungan Indonesia (HAKLI) - Kesehatan lingkungan adalah suatu kondisi lingkungan yang mampu menopang keseimbangan ekologi yang dinamis antara manusia \& lingkungannya untuk mendukung tercapainya kualitas hidup manusia yang sehat \& bahagia. (HAKLI, 2014). Jadi kesehatan lingkungan sangat penting dalam mendukung terciptanya kehidupan manusia yang berkualitas dalam usaha membangun keluarga yang sehat dan bahagia.

Menurut World Health Organization (WHO) ruang lingkup kesehatan lingkungan meliputi:

1. Penyediaan Air Minum.

2. Pengelolaan air buangan \& pengendalian pencemaran.

3. Pembuangan sampah padat.

4. Pengendalian vektor. (Pengendalian vektor adalah semua usaha yang dilakukan untuk mengurangi atau menurunkan populasi vektor dengan maksud mencegah atau pemberantas penyakit yang ditularkan vektor atau gangguan yang diakibatkan oleh vektor.)

5. Pencegahan atau pengendalian pencemaran tanah oleh ekskreta manusia. (Ekskreta maksudnya semua zat yang tidak dipakai lagi oleh tubuh dan yang harus dikeluarkan dari dalam tubuh.)

6. Higiene makanan, termasuk higiene susu.

7. Pengendalian pencemaran udara.

8. Pengendalian radiasi.

9. Kesehatan kerja

10. Pengendalian kebisingan.

11. Perumahan \& pemukiman.

12. Aspek kesling \& transportasi udara.

13. Perencanaan daerah \& perkotaan.

14. Pencegahan kecelakaan.

15. Rekreasi umum \& pariwisata.

16. Tindakan-tindakan sanitasi yang berhubungan dengan keadaan epidemic atau wabah, bencana alam \& perpindahan penduduk. 
17. Tindakan pencegahan yang diperlukan untuk menjamin lingkungan.

Untuk keperluan pelatihan literasi informasi kesehatan lingkungan pada ibu ibu kader PKK di Kecamatan Jatinangor akan difokuskan pada aspek penyediaan air minum, pengelolaan sampah, dan kesehatan makanan.

Terdapat beberapa pengertian literasi informasi. Salah satu pengertian literasi informasi yang dianggap komprehensif adalah yang dirumuskan oleh National Forum for Information Literacy yang menyatakan: information literacy encompasses knowledge of one's information concerns and needs, and the ability to identify, locate, evaluate, organize, and effectively create, use and communicate information to address issues or problems at hand; it is a prerequisite for participating effectively in the information society, and it is part of the basic human right of life-long learning. (Lien, 2010). Jadi literasi informasi merupakan pengetahuanyang dimiliki oleh seseorang mengenai kebutuhan, kemampuan untuk mengidentifikasi, menemukan sumber, mengevaluasi, mengorganisir informasi, serta menciptakan, memanfaatkan dan mengkomunikasikan informasi secara efektif untuk mengatasi masalah yang dihadapi; literasi informasi merupakan pra-syarat untuk berpartisipasi dalam masyarakat informasi, dan literasi informasi merupakan bagian dari hak azasi manusia dalam hal belajar sepanjang hayat.

Dengan demikian kemampuan literasi informasi merupakan kemampuan yang sangat penting yang harus dimiliki setiap orang agar mampu belajar secara mandiri sepanjang hayat (lifelong learning) sehingga mampu mengatasi masalah yang dihadapi secara tepat. Selanjutnya mereka yang mampu mengatasi masalah pribadi dengan tepat juga akan mampu berpartisipasi secara aktif dan kreatif dalam mengatasi masalah sosial di lingkungannya, sehingga mereka akan menjadi manusia yang unggul yang akan mampu bersaing secara global dalam masyarakat informasi.

Terdapat empat model literasi informasi, yaitu model The Big 6, The seven Pilars of Information Literacy, The Empowering 8, danThe Seven Faces of Information Literacy. Setiap model memiliki ciri khas tersendiri dan relevan untuk diterapkan pada kelompok pembelajar tertentu.

Dalam pelatihan literasi informasi kesehatan lingkungan untuk para ibu kader PKK ini digunakan model literasi informasi The Seven Pilars of Information Literacy.Model ini dipilih karena merupakan model literasi informasi yang relatif lebih mudah untuk diterapkan dan relevan dengan karakteristik target.

Model The Seven Pilars of Information Literacy membagi tahap literasi informasi dalam dua tahap. Tahap pertama terdiri dari empat pilar utama, yaitu: Pilar 1. Menyadari adanya kebutuhan informasi, menge- tahui informasi yang sudah diketahui, mengetahui apa yang tidak diketahui dan mengidentifikasi kesenjangan antara yang diketahui dengan yang tidak diketahui.

Pilar 2. Membedakan cara mengatasi kesenjangan, mengetahui sumber informasi mana yang paling besar peluangnya memuaskan kebutuhan.

Pilar 3. Membangun strategi untuk menentukan lokasi informasi. Contoh bagaimana mengembangkan dan memperbaiki strategi penelusuran yang efektif.

Pilar 4. Menentukan lokasi dan akses informasi, mengetahui bagaimana mengakses sumber infotmasi dan memeriksa alat untuk akses dan temu balik informasi.

Selanjutnya tahap kedua terdiri dari tiga pilar yang merupakan tahap lanjutan dengan tingkat kemampuan merumuskan konsep yang lebih tinggi, yaitu:

Pilar 5. Membandingkan dan mengevaluasi, mengetahui bagaimana relevansi dan kualitas informasi yang ditemukan.

Pilar 6. Mengorganisasi, menerapkan dan mengkomunikasikan, mengetahui bagaimana merangkaikan informasi baru dengan informasi lama, mengambil tindakan atau membuat keputusan dan akhirnya bagaimana berbagi hasil temuan informasi tersebut dengan orang lain.

Pilar 7. Sintesis dan menciptakan, mengetahui bagaimana mengasimilasikan informasi dari berbagai jenis sumber untuk keperluan menciptakan pengetahuan baru.

Melalui pelatihan litersi informasi kesehatan lingkungan yang diberikan pada ibu-ibu kader PKK di Kecamatan Jatinangor, maka diharapkan para kader PKK akan menularkan kemampuan literasi informasi kesehatan lingkungan yang telah diperolehnya kepada ibu-ibu yang lain yang berada di sekitarnya, sehingga pada akhirnya diharapkan seluruh ibu-ibu yang berada di Kecamatan Jatinangor memiliki kemampuan literasi informasi kesehatan lingkungan.

Konsep literasi informasi yang diberikan pada pelatihan literasi informasi kesehatan lingkungan dapat diaplikasikan pula pada literasi informasi dalam bidang lain, misalnya literasi informasi bencana, literasi informasi pemasaran, dll.

\section{METODE}

Metode yang digunakan dalam pelatihan literasi informasi kesehatan lingkungan terdiri dari ceramah dan praktek. Materi ceramah tentang kesehatan lingkungan yang meliputi penyediaan air minum yang sehat, penyediaan makanan yang sehat dan pengelolaan 
sampah rumah tangga. Dilanjutkan dengan kegiatan praktek berlatih menerapkan langkah-langkah literasi informasi.

Proses penyampaian materi literasi informasi kesehatan lingkungan berupa ceramah disampaikan oleh pakar informasi kesehatan lingkungan. Peserta dikondisikan untuk menyimak materi yang disampaikan sebagai bahan untuk kegiatan praktek pelatihan literasi informasi kesehatan lingkungan. Pada bagian akhir penyampaian materi peserta dipersilahkan untuk bertanya apabila ada yang masih belum mengerti atau ada hal-hal yang ingin didiskusikan dengan narasumber.

Tahap kedua berupa praktek pelatihan literasi informasi kesehatan lingkungan dimana peserta dibagi menjadi kelompok-kelompok kecil terdiri dari masingmasing lima orang. Setiap kelompok diberi satu kasus tentang kesehatan lingkungan dan mereka dibimbing untuk mencari informasi untuk memecahkan masalah tersebut.

\section{HASIL DAN PEMBAHASAN}

Pelatihan literasi informasi kesehatan lingkungan dengan target para ibu rumah tangga yang menjadi kader PKK merupakan langkah yang sangat tepat. Mengingat para ibu rumah tangga (kader PKK) dapat menularkan kemampuannya pada keluarganya dan pada ibu-ibu yang lain yang ada di lingkungannya, sehingga akan menjadi lebih banyak lagi anggota masyarakat yang memiliki kemampuan literasi informasi kesehatan lingkungan.

Dalam pelatihan literasi informasi kesehatan lingkungan untuk para ibu ibu rumah tangga yang menjadi kader PKK digunakan model The Seven Pilars of Information Literacy. Model ini dipilih karena dianggap relevan dengan karakteristik target, yaitu tingkat pendidikan paling rendah SMP dan jenis kelamin perempuan.

Pelaksanaan pelatihan terdiri dari dua tahap. Tahap pertama berupa penyampaian materi dengan model ceramah dan tanya jawab untuk hal-hal yang belum dimengerti. Tahap kedua berupa pelatihan untuk mengaplikasikan teori tentang literasi informasi dengan model The Seven Pilars of Information Literacy.

Tahap pertama berupa ceramah tentang pentingnya memelihara kesehatan lingkungan, konsep umum literasi informasi yang terdiri dari pengertian literasi informasi, manfaat literasi informasi, model The Seven Pilars of Information Literacy, manfaat literasi informasi kesehatan.

Tahap kedua berupa praktek pelatihan literasi informasi kesehatan lingkungan dimana peserta dibagi menjadi kelompok-kelompok kecil terdiri dari masingmasing lima orang. Setiap kelompok diberi satu kasus tentang kesehatan lingkungan dan mereka dibimbing untuk mencari informasi untuk memecahkan masalah tersebut.
Langkah-langkah pencarian informasi dalam memecahkan masalah harus mengikuti model The Seven Pilars of Information Literacy yang terdiri dari:

Tahap pertama menyadari adanya kebutuhan informasi, mengetahui apa yang telah diketahui, mengetahui apa yang tidak diketahui dan mengidentifikasi kesenjangan antara yang diketahui dengan yang tidak diketahui. Peserta pelatihan diminta menuliskan hal-hal yang sudah mereka ketahui dan yang belum diketahui berkaitan dengan contoh kasus yang diberikan, selanjutnya didiskusikan aspek-aspek yang merupakan kesenjangan antara yang sudah diketahui dan yang belum diketahui.

Langkah kedua membedakan cara mengatasi kesenjangan, mengetahui sumber informasi mana yang paling besar peluangnya memuaskan kebutuhan. Para peserta diberikan contoh untuk membandingkan antara berbagai media yang mungkin digunakan: buku, majalah, internet, dsb. Mereka dipersilahkan menentukan media yang akan digunakan sebagai sumber informasi yang akan dicari

Langkah ketiga membangun strategi untuk menentukan lokasi informasi. Contoh bagaimana mengembangkan dan memperbaiki strategi penelusuran yang efektif. Para peserta diberi penjelasan tentang bagaimana cara menentukan kata kunci yang tepat untuk informasi yang akan dicari.

Langkah keempat menentukan lokasi dan akses informasi, mengetahui bagaimana mengakses sumber informasi dan memeriksa alat untuk akses dan temu balik informasi.Para peserta diberi penjelasan tentang dimana bisa mendapatkan sumber-sumber informasi. Misalnya dijelaskan kalau akan mencari informasi yang ada di buku, suratkabar, majalah, internet, dll bisa datang ke perpustakaan. Selanjutnya dijelaskan bagaimana cara mencari sumber informasi yang ada di perpustakaan, misalnya diawali dengan menggunakan katalog yang ada di perpustakaan, lalu mencari buku yang ada di rak berdasarkan nomor panggil buku tersebut, selanjutnya dijelaskan bagaimana cara mencari informasi yang ada dalam sebuah buku, misalnya diawali dengan melihat daftar isi dari buku tersebut.

Langkah kelima membandingkan dan mengevaluasi, mengetahui bagaimana relevansi dan kualitas informasi yang ditemukan. Pada peserta dijelaskan bagaimana menilai kualitas informasi. Mereka dipersilahkan untuk mendiskusikan informasi yang sudah diperoleh berdasarkan karakteristik kualitas informasi, yaitu relevansi, akurasi, validitas, aktualitas, dan kelengkapannya.

Langkah keenam mengorganisasi, menerapkan dan mengkomunikasikan, mengetahui bagaimana merangkaikan informasi baru dengan informasi lama, mengambil tindakan atau membuat keputusan dan akhirnya bagaimana berbagi hasil temuan informasi tersebut dengan orang lain. Peserta dibimbing untuk 
menuliskan informasi baru yang diperoleh dan mencoba mengaitkan atau merangkai berbagai informasi yang ada untuk menjadi sebuah tulisan.

Langkah ketujuh menintesis dan menciptakan, mengetahui bagaimana mengasimilasikan informasi dari berbagai jenis sumber untuk keperluan menciptakan pengetahuan baru. Pada peserta dijelaskan bagaimana mereka dapat merangkaikan berbagai informasi yang telah diperoleh menjadi sebuah karangan atau cerita yang merupakan sebuah informasi baru. Peserta dibimbing untuk membuat sebuah karangan. Selanjutnya dijelaskan bagaimana peserta dapat mengkomunikasikan tulisannya tersebut pada orang lain, misalnya melalui komunikasi antar pribadi, komunikasi kelompok atau melalui media massa misalnya memasukkan tulisannya ke sebuah surat kabar.

Hasil dari pelatihan adalah target mengetahui dan memahami tujuh langkah literasi informasi kesehatan. Empat pilar pertama merupakan langkah-langkah bagaimana mendapatkan informasi yang dibutuhkan untuk mengatasi masalah kesehatan. Tiga pilar berikutnya merupakan cara bagaimana memilah informasi yang sudah diperoleh, selanjutnya menyusun informasi tersebut sehingga menjadi sebuah informasi baru yang bermakna, dan mengkomunikasikan informasi tersebut kepada orang lain.

Ibu-ibu kader PKK memiliki kemampuan literasi informasi kesehatan lingkungan yang terdiri dari mampu mengidentifikasi masalah yang untuk mengatasinya membutuhkan informasi, mampu mengidentifikasi sumber informasi yang memiliki peluang besar mengandung informasi yang dibutuhkan, mampu menetapkan teknik untuk menelusur informasi yang dibutuhkan, mampu mengakses sumber informasi yang telah dipilih, mampu mengevaluasi kualitas informasi yang diperoleh, mampu mengorganisir informasi yang diperoleh dan mampu mensinergikan informasi dari berbagai sumber untuk menciptakan informasi yang baru dan mengkomunikasikannya pada orang lain.

Kemampuan literasi informasi kesehatan lingkungan pada ibu-ibu kader PKK akan memberikan dampak positif bagi lingkungan sosial baik secara sempit maupun secara luas. Dampak sosial secara sempit, ibu-ibu kader PKK akan menularkan kemampuannya pada anggota keluarga yang bersangkutan, sedangkan pengaruh secara luas adalah para ibu-ibu kader PKK akan mengajarkan kemampuan literasi informasinya pada ibuibu lain yang merupakan anggota binaannya. Dengan demikian seluruh ibu-ibu anggota PKK di Kecamatan Jatinangor diharapakan akan memiliki kemampuan literasi informasi kesehatan lingkungan.

Kemampuan literasi informasi kesehatan lingkungan diharapkan akan berdampak pula pada kesadaran akan pentingnya memelihara lingkungan yang selanjutnya akan berdampak pula pada perilaku menjaga kebersihan dan kesehatan lingkungan. Hal ini merupakan dampak positif yang akan dirasakan oleh masyarakat secara luas.

\section{SIMPULAN}

Berdasarkan monitoring dan evaluasi yang dilaksanakan melalui FGD bersama perwakilan ibu-ibu kader PKK dapat diketahui bahwa pelaksanaan program pengabdian kepada masyarakat (PKM) ini secara keseluruhan telah mencapai target yang telah direncanakan yaitu:

1. Ibu-ibu kader PKK telah memiliki kemampuan untuk menyadari bahwa ketika mereka menghadapi suatu masalah yang berkaitan dengan kesehatan lingkungan, maka yang harus dilakukan adalah mencari informasi tentang kesehatan lingkungan.

2. Ketika mencari informasi yang dibutuhkan, Ibuibu kader PKK lebih mengutamakan melakukan komunikasi antar pribadi seperti bertanya pada teman, tetangga atau yang lainnya yang dianggap mengetahui. Sumber informasi yang dipergunakan berikutnya adalah dari televisi dan buku.

3. Ketika sudah mendapatkan informasi yang dibutuhkan mereka mencatatnya untuk disimpan untuk keperluan sendiri/keluarga dan juga untuk diberikan kepada orang lain.

4. Ibu-ibu kader PKK telah mampu menerapkan langkah-langkah literasi informasi dalam pencarian informasi tentang kesehatan lingkungan

5. Ibu-ibu kader PKK menyatakan bahwa dengan menerapkan langkah-langkah literasi informasi setiap mereka menyadari menghadapi masalah merupakan hal yang sangat membantu dalam mengatasi masalah yang dihadapinya.

6. Ibu-ibu kader PKK akan mengajarkan langkahlangkah literasi informasi pada anggota kelompoknya.

\section{UCAPAN TERIMA KASIH}

Selama pelaksanaan PKM ini dari mulai persiapan, pelaksanaan di lapangan, monitoring dan evaluasi sampai pembuatan laporan akhir telah begitu banyak mendapatkan bantuan dari berbagai pihak. Oleh karena itu dengan segala kerendahan hati kami menghaturkan terima kasih kepada Dr. Dadang Rahmat Hidayat, S.Sos,SH., selaku Dekan Fikom Unpad beserta Wakil Dekan I dan Wakil Dekan II Fikom Unpad yang telah memberikan kesempatan kepada kami untuk melaksanakan kegiatan PKM ini. Kami juga menghaturkan terima kasih kepada Bapak Camat Kecamatan Jatinangor Sumedang, Ibu Ketua Tim Penggerak PKK Kecamatan Jatinangor yang telah mengijinkan kami untuk melaksanakan PKM di wilayah Kecamatan Jatinangor. Rekan-rekan dosen dari Program Studi Keperawatan Unpadyang telah berkenan menjadi narasumber, Bapak Andri Yanto, M.Ikom selaku Koordinator Bale Pabukon Unpad yang telah mengijinkan kami menggunakan Bale Pabukon dalam program PKM, para ibu kader PKK Kecamatan Jatinangor yang telah hadir sebagai peserta, para mahasiswa yang telah banyak membantu dalam pelaksanaan PKM ini. Semoga Alloh Swt membalas semua kebaikan Bapak dan Ibu. 


\section{DAFTAR PUSTAKA}

Himpunan Ahli Kesehatan Lingkungan Indonesia (HAKLI), 2016. Pengertian Kesehatan Ligkungan. https://direktoriorganisasiprofesi. Wordpress.com/

Lien, D.A et all. 2010. Literasi Informasi: 7 Langkah Knowledge Management. Jakarta: PUAJ
Notoatmojo, S. 2007. Kesehatan Masyarakat: Ilmu dan Seni. Jakarta: Rineka Cipta.

Yuniarti, N. 2015. Dampak pencemaran Lingkungan Terhadap Ekosisitem dan Masyarakat di Kecamatan Jatinangor Kabupaten Sumedang. Bandung: Kementerian Agama RI. 